JURNAL ILMU KESEHATAN BHAKTI HUSADA:

HEALTH SCIENCES JOURNAL

VOL. 12 NO. 02, DESEMBER 2021

DOI: $10.34305 / \mathrm{JIKBH} . \mathrm{V} 12 \mathrm{I} 2.326$
Ciptaan disebarluaskan di bawah

Lisensi Creative Commons Atribusi-

NonKomersial-BerbagiSerupa 4.0

\title{
PERILAKU MEROKOK DAN KEBERADAAN PEROKOK DI LINGKUNGAN DENGAN KADAR KARBON MONOKSIDA PADA PELAJAR DI KABUPATEN INDRAMAYU
}

${ }^{1}$ Andy Muharry, ${ }^{2}$ Puji Laksmini, ${ }^{3}$ Hendra Rohman, ${ }^{4}$ Lusi Fitriah Sari, ${ }^{5}$ Ana Herlina, ${ }^{6}$ Tetha Normalitha

${ }^{1,2}$ Universitas Siliwangi, ${ }^{3}$ Politeknik Kesehatan Bhakti Setya Indonesia 4,5,6 Dinas Kesehatan Kabupaten Indramayu

andy.muharry@unsil.ac.id

\begin{abstract}
Abstrak
Perilaku merokok saat ini tidak hanya dilakukan oleh orang dewasa akan tetapi dilakukan juga oleh kalangan remaja. Data SDKI menunjukkan bahwa trend remaja perokok setiap tahun terus mengalami peningkatan. Karbon monoksida yang terdapat dalam asap rokok memiliki sifat beracun dan karsinogen yang dapat menimbulkan masalah kesehatan. Tujuan penelitian adalah menganalisis hubungan pengetahuan tentang dampak buruk rokok, keberadaan perokok di lingkungan sekolah, keberadaan perokok di lingkungan keluarga, teman dekat perokok dengan kadar CO pada pelajar. Populasi adalah pelajar SMP kelas satu yang terdata dalam program skrining perilaku merokok tahun 2020. Sampel adalah remaja SMP yang memenuhi kriteria inklusi, diambil dengan metode total sampling. Uji chi square dilakukan untuk mengetahui hubungan variabel pengetahuan tentang dampak buruk rokok, keberadaan keluarga perokok, keberadaan perokok di sekolah dan teman dekat perokok dengan kadar CO. Uji regresi logistik dilakukan untuk mengetahui variabel yang dominan berhubungan dengan kadar CO pada remaja. Hasil penelitian menunjukkan variabel yang berhubungan dengan kadar CO yaitu keberadaan anggota keluarga perokok, keberadaan teman dekat perokok dan perilaku merokok. Hasil analisis multivariat menunjukkan bahwa variabel yang dominan berhubungan dengan kadar CO yaitu perilaku merokok. Disarankan perlu adanya upaya peningkatan kesadaran kepada para remaja untuk menghindari perilaku merokok.
\end{abstract}

Kata Kunci: Karbon monoksida, Pelajar, Perilaku merokok, Teman dekat perokok 
JURNAL ILMU KeSEHATAN BHAKTI HUSADA:

HEALTH SCIENCES JOURNAL

VOL. 12 No. 02, DESEMBER 2021

DOI: $10.34305 / \mathrm{JIKBH} . \mathrm{V} 12 \mathrm{I} 2.326$

\section{Pendahuluan}

Perilaku merokok merupakan fenomena yang sering dijumpai di masyarakat. Perilaku ini bila diamati, banyak dilakukan oleh orang dewasa namun tidak sedikit juga dilakukan oleh para remaja. Data hasil Survei Demografi dan Kesehatan (SDKI) tahun 2017 menunjukkan $55 \%$ laki-laki adalah perokok dan perempuan perokok 1\%. Sebesar 31\% perempuan dan 21\% laki-laki mulai merokok sebelum usia 13 tahun. Separuh pria menghisap lebih dari 10 batang rokok per harinya. Terdapat peningkatan remaja laki-laki yang merokok sebesar 5\% jika dibandingkan dengan data SDKI tahun 2007 (Badan Kependudukan dan Keluarga Bencana Nasional et al., 2018). Remaja dalam siklus kehidupan manusia merupakan suatu tahapan dimana terjadi banyak perubahan, mulai dari perubahan fisik, mental, psikologis dan sosial.

Pusat Data dan Informasi Kementrian Kesehatan RI (2017) membagi masa remaja menjadi tiga masa yaitu remaja awal (10-12 tahun), remaja tengah (13-15 tahun) dan remaja akhir (16-19 tahun). Dalam masa pertumbuhan dan perkembangannya seorang remaja memiliki
Ciptaan disebarluaskan di bawah Lisensi Creative Commons AtribusiNonKomersial-BerbagiSerupa 4.0 Internasional

karakteristik khusus pada setiap tahapannya. Pada tahap awal, perkembangan remaja ditandai dengan mulai mencoba berbagai peran dan mencari identitas. Remaja mulai mencari afiliasi dengan teman sebaya untuk menghadapi ketidakstabilan akibat perubahan yang cepat, lebih banyak teman dengan jenis kelamin yang sama, namun mulai mengeksplorasi kemampuan untuk menarik lawan jenis (Wulandari, 2014). Berbagai persoalan muncul seiring dengan pertumbuhan dan perkembangan remaja. Berbagai perilaku berisiko dilakukan oleh remaja seperti perilaku merokok, konsumsi minuman beralkohol, narkoba dan seks bebas. Merokok merupakan perilaku yang paling sering dilakukan oleh remaja. Seorang individu yang mengenal rokok pada usia remaja akan lebih sulit untuk melepaskan diri dari kebiasaan tersebut jika dibandingkan dengan orang yang memulainya di saat usia lebih dewasa (Wijayanti \& Dewi, 2017).

Kebiasaan merokok yang dilakukan oleh remaja dapat menimbulkan persoalan tersendiri jika tidak segera diatasi. Odukoya et al., (2013) menyebutkan bahwa tembakau yang terdapat dalam rokok dapat menimbulkan kecanduan dan menimbulkan 
JURNAL ILMU KeSEHATAN BHAKTI HUSADA:

HEALTH SCIENCES JOURNAL

VOL. 12 No. 02, DESEMBER 2021

DOI: $10.34305 / \mathrm{JIKBH} . \mathrm{V} 12 \mathrm{I} 2.326$

dampak berbahaya bagi kesehatan. Ketika sebatang rokok dibakar terjadi pelepasan zat-zat kimia berbahaya yang bersifat karsinogenik. Karbon monoksida (CO) adalah salah satu gas yang terdapat pada asap rokok. $\mathrm{CO}$ adalah gas yang memiliki sifat tidak berwarna, tidak berasa, tidak berbau dan bersifat beracun. Karbon monoksida dikenal sebagai silent killer, gas ini apabila memasuki sirkulasi darah akan berikatan dengan hemoglobin dengan daya ikat 250 kali lebih kuat dibanding dengan daya ikat oksigen dengan hemoglobin. Kondisi seperti ini dapat menimbulkan gangguan sirkulasi darah dan jantung (Putri, 2018). Selain itu Hosseinpoor et al., (2011) menyatakan bahwa salah satu penyebab utama kematian bayi prematur dan disabilitas adalah kebiasaan merokok.

Dalam hal konsumsi rokok, Indonesia berada pada posisi ketiga setelah China dan India. kondisi ini cenderung mengalami peningkatan setiap tahunnya. Pada tahun 2001 jumlah batang rokok yang dikonsumsi sebesar 182 miliar batang meningkat menjadi 260,8 miliar batang pada tahun 2009. Provinsi dengan dengan prevalensi merokok tertinggi di Indonesia adalah Jawa Barat sebesar 32,7\% lebih
Ciptaan disebarluaskan di bawah Lisensi Creative Commons AtribusiNonKomersial-BerbagiSerupa 4.0 Internasional

tinggi dibandingkan dengan prevalensi nasional (29\%). Menurut Global Youth Tobacco Survey, remaja usia 13-15 tahun mulai merokok di usia 12-13 tahun yakni sebesar $43,2 \%$ dan sebanyak $11,4 \%$ mulai merokok pada usia 14-15 tahun (Pusat Data dan Informasi Kementrian Kesehatan RI, 2018)

Beberapa hasil studi yang telah dilakukan sebelumnya bahwa perilaku merokok remaja berkaitan erat dengan adanya pengaruh lingkungan seperti pengaruh teman sebaya, adanya anggota keluarga perokok dan pengetahuan yang kurang tentang dampak buruk rokok (Isa et al., 2017; Riadinata et al., 2018; Rochayati \& Hidayat, 2015). Jumlah batang rokok yang dikonsumsi akan mempengaruhi tinggi rendahnya kadar CO pada seseorang (Putri, 2018).

Suatu studi tentang perilaku berisiko remaja di Kampung Nelayan Indramayu menunjukkan bahwa perilaku berisiko yang sering dilakukan oleh remaja adalah perilaku merokok (Iustitiani \& Ajisuksmo, 2017). Hasil kegiatan skrining perilaku merokok disalah satu sekolah menengah atas di Kabupaten Indramayu menunjukkan sebanyak $76 \%$ siswa adalah perokok yang 
JURNAL ILMU KeSEHATAN BHAKTI HuSADA:

HEALTH SCIENCES JOURNAL

VOL. 12 NO. 02, DESEMBER 2021

DOI: $\underline{10.34305 / J I K B H . V 12 I 2.326}$

telah memiliki kebiasaan merokok lebih dari satu tahun. Diantara siswa perokok tersebut ditemukan sebesar 5\% siswa dengan kadar $\mathrm{CO}>7$ ppm (Salim, 2018). Tujuan penelitian adalah menganalisis hubungan pengetahuan tentang dampak buruk rokok, keberadaan perokok di lingkungan sekolah, keberadaan perokok di lingkungan keluarga, teman dekat perokok dengan kadar CO pada pelajar di Kabupaten Indramayu.

\section{Metode}

Data yang digunakan adalah data sekunder hasil kegiatan program skrining perilaku merokok yang telah dilakukan oleh Dinas Kesehatan Kabupaten Indramayu. Variabel bebas dan variabel terikat diambil pada satu waktu. Populasi adalah pelajar SMP kelas satu yang tercatat dalam program skrining perilaku merokok yaitu 398 orang. Sampel penelitian ini adalah remaja SMP yang memenuhi kriteria inklusi dan eksklusi. Pengambilan sampel dilakukan dengan metode total sampling yang memenuhi kriteria inklusi yaitu sebanyak 383 orang. Kriteria inklusi adalah responden yang terdata dalam program skrining perilaku merokok pada tahun 2020. Kriteria eksklusi adalah responden yang datanya tidak
Ciptaan disebarluaskan di bawah Lisensi Creative Commons AtribusiNonKomersial-BerbagiSerupa 4.0 Internasional

lengkap. Uji chi square digunakan untuk mengetahui hubungan variabel pengetahuan tentang dampak buruk rokok, keberadaan keluarga perokok, keberadaan perokok di sekolah dan teman dekat perokok dengan kadar CO. Analisis selanjutnya dilakukan uji regresi logistik untuk mengetahui variabel yang dominan berhubungan dengan kadar CO pada remaja. Tingkat kepercayaan yang digunakan yaitu 95\% CI dengan $\alpha 5 \%$.

\section{Hasil dan Pembahasan}

Penelitian dilakukan dengan menganalisis data sekunder hasil kegiatan program skrining perilaku merokok remaja dengan sasaran adalah pelajar SMP yang menjadi target sasaran program skrining perilaku merokok. Sebanyak empat sekolah menengah pertama dijadikan sasaran program skrining perilaku merokok. Jumlah data yang tersedia sebanyak 398 data sampel. Sebanyak 383 data sampel memenuhi kriteria inklusi. Sejumlah 15 data sampel tidak lengkap sehingga tidak digunakan. Waktu pengambilan data dilakukan selama tahun 2020 .

Nilai kadar $\mathrm{CO}$ diperoleh dengan cara melihat jawaban dan hasil pengukuran yang terdapat pada instrumen yang telah 
JURNAL ILMU KeSEHATAN BHAKTI HUSADA:

HEALTH SCIENCES JOURNAL

VOL. 12 No. 02, DESEMBER 2021

DOI: $10.34305 / \mathrm{JIKBH} . \mathrm{V} 12 \mathrm{I} 2.326$

diisi, yaitu pada kolom A1 (hasil pemeriksaan karbon monoksida (COppm). Hasil pengukuran berupa nilai antara 01-30. Kategori kadar CO dikelompokkan menjadi dua yaitu normal dan berbahaya. Hasil pengukuran dikategorikan normal apabila nilai CO berada pada interval 01-06, dan berbahaya jika berada pada interval 07-30.
Ciptaan disebarluaskan di bawah Lisensi Creative Commons AtribusiNonKomersial-BerbagiSerupa 4.0 Internasional.

Tabel 1 menunjukkan hasil analisis univariat responden berdasarkan pengetahuan tentang dampak buruk rokok, keberadaan anggota keluarga perokok, keberadaan perokok di lingkungan sekolah, keberadaan teman dekat perokok, perilaku merokok dan variabel terikat yaitu kadar CO.

Tabel 1. Distribusi responden berdasarkan variabel bebas perilaku merokok dan keberadaan perokok di lingkungan dengan kadar CO pada pelajar SMP di Kabupaten Indramayu

\begin{tabular}{cllcc}
\hline & \multicolumn{1}{c}{ Variabel } & \multicolumn{1}{c}{ Kategori } & $\begin{array}{c}\text { Jumlah } \\
(\mathbf{n = 3 8 3 )}\end{array}$ & Persentase \\
\hline 1. & Pengetahuan tentang & Tidak mengetahui & 297 & 77,5 \\
& dampak buruk rokok & Mengetahui & 86 & 22,5 \\
\hline 2. & Keberadaan anggota & Ada & 300 & 78,3 \\
& keluarga perokok & Tidak ada & 83 & 21,7 \\
\hline 3. & Keberadaan perokok & Ada & 329 & 85,9 \\
& di sekolah & Tidak ada & 54 & 14,1 \\
\hline 4. & Teman dekat perokok & Ada & 202 & 52,7 \\
& & Tidak ada & 181 & 47,3 \\
\hline 5. & Perilaku merokok & Ya & 161 & 42 \\
& & Tidak & 222 & 58 \\
\hline 6. & Kadar CO & Berbahaya & 85 & 22,2 \\
& & Normal & 298 & 77,8 \\
\hline
\end{tabular}

Tabel 1 diatas menunjukkan bahwa $77,5 \%$ responden tidak mengetahui dampak buruk rokok terhadap kesehatan. $78,3 \%$ responden dilingkungan keluarga terdapat anggota keluarga perokok. $85,9 \%$ responden di lingkungan sekolahnya terdapat perokok. $52,7 \%$ responden memiliki teman dekat perokok. 58\% responden adalah perokok. $77,8 \%$ responden berada pada kategori kadar CO normal. Ada tidaknya hubungan antara kadar CO dengan masing-masing variabel bebas dilakukan uji chi-square. Hasil analisis bivariat dapat dilihat pada tabel berikut ini: 
JURNAL ILMU KeSEHATAN BHAKTI HUSADA:

HEALTH SCIENCES JOURNAL

VOL. 12 No. 02, DESEMBER 2021

DOI: $10.34305 / \mathrm{JIKBH} . \mathrm{V} 12 \mathrm{I} 2.326$
Ciptaan disebarluaskan di bawah

Lisensi Creative Commons Atribusi-

NonKomersial-BerbagiSerupa 4.0

Internasional.

Tabel 2. Distribusi responden berdasarkan variabel bebas dan variabel terikat perilaku merokok dan keberadaan perokok di lingkungan dengan kadar CO pada pelajar SMP di Kabupaten Indramayu

\begin{tabular}{|c|c|c|c|c|c|c|c|c|}
\hline \multirow{3}{*}{ Variabel } & \multicolumn{4}{|c|}{ Kadar CO } & \multicolumn{2}{|c|}{ Jumlah } & \multirow{3}{*}{$\begin{array}{c}P \\
\text { value }\end{array}$} & \multirow{3}{*}{$\begin{array}{c}\text { OR } \\
(95 \% C I)\end{array}$} \\
\hline & \multicolumn{2}{|c|}{ Berbahaya } & \multicolumn{2}{|c|}{ Normal } & & & & \\
\hline & $\mathbf{N}$ & $\%$ & $\mathbf{N}$ & $\%$ & $\mathbf{N}$ & $\%$ & & \\
\hline $\begin{array}{l}\text { Pengetahuan tentang } \\
\text { dampak buruk rokok } \\
\text { - Tidak Mengetahui } \\
\text { - Mengetahui }\end{array}$ & $\begin{array}{l}64 \\
21 \\
\end{array}$ & $\begin{array}{l}21,5 \\
24,4 \\
\end{array}$ & $\begin{array}{l}233 \\
65 \\
\end{array}$ & $\begin{array}{l}78,5 \\
75,6 \\
\end{array}$ & $\begin{array}{r}297 \\
86 \\
\end{array}$ & $\begin{array}{l}100 \\
100 \\
\end{array}$ & 0,573 & $\begin{array}{c}0,850 \\
(0,484-1,495)\end{array}$ \\
\hline $\begin{array}{l}\text { Keberadaan Anggota } \\
\text { Keluarga perokok } \\
\text { - Ada } \\
\text { - Tidak Ada }\end{array}$ & $\begin{array}{l}71 \\
14 \\
\end{array}$ & $\begin{array}{l}23,7 \\
16,9 \\
\end{array}$ & $\begin{array}{r}229 \\
69 \\
\end{array}$ & $\begin{array}{l}76,3 \\
83,1 \\
\end{array}$ & $\begin{array}{r}300 \\
83 \\
\end{array}$ & $\begin{array}{l}100 \\
100 \\
\end{array}$ & 0,187 & $\begin{array}{c}1,528 \\
(0,811-2,878) \\
\end{array}$ \\
\hline $\begin{array}{l}\text { Keberadaan Perokok } \\
\text { di Sekolah } \\
\text { - Ya } \\
\text { - Tidak }\end{array}$ & $\begin{array}{r}80 \\
5 \\
\end{array}$ & $\begin{array}{c}24,3 \\
9,3 \\
\end{array}$ & $\begin{array}{r}249 \\
49 \\
\end{array}$ & $\begin{array}{l}75,7 \\
90,7 \\
\end{array}$ & $\begin{array}{r}329 \\
54 \\
\end{array}$ & $\begin{array}{l}100 \\
100 \\
\end{array}$ & 0,014 & $\begin{array}{c}3,149 \\
(1,213-8,174)\end{array}$ \\
\hline $\begin{array}{l}\text { Teman dekat } \\
\text { Perokok } \\
\text { - Ya } \\
\text { - Tidak }\end{array}$ & $\begin{array}{l}58 \\
27\end{array}$ & $\begin{array}{l}28,7 \\
14,9\end{array}$ & $\begin{array}{l}144 \\
154\end{array}$ & $\begin{array}{l}71,3 \\
85,1\end{array}$ & $\begin{array}{c}202 \\
181\end{array}$ & $\begin{array}{l}100 \\
100\end{array}$ & 0,001 & $\begin{array}{c}2,297 \\
(1,379-3,826)\end{array}$ \\
\hline 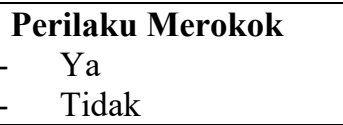 & $\begin{array}{l}63 \\
22 \\
\end{array}$ & $\begin{array}{l}39,1 \\
9,9\end{array}$ & $\begin{array}{l}98 \\
200\end{array}$ & $\begin{array}{l}60,9 \\
77,8\end{array}$ & $\begin{array}{l}161 \\
222\end{array}$ & $\begin{array}{l}100 \\
100\end{array}$ & 0,000 & $\begin{array}{c}5,844 \\
(3,393-10,051)\end{array}$ \\
\hline
\end{tabular}

Hasil tabulasi silang pada tabel 2 menunjukkan bahwa 297 responden yang tidak mengetahui dampak buruk rokok sebesar 78,5\% termasuk dalam kategori kadar CO normal dan 21,5\% dalam kategori kadar CO berbahaya. Sedangkan dari 86 responden yang mengetahui dampak buruk rokok sebesar $75,6 \%$ termasuk dalam kategori kadar $\mathrm{CO}$ normal dan sebesar $24,4 \%$ dalam kategori berbahaya. Hasil analisis chi-square hubungan pengetahuan tentang dampak buruk rokok terhadap kadar $\mathrm{CO}$ didapatkan nilai $\mathrm{p}>0,05$ sehingga menunjukkan tidak terdapat hubungan antara pengetahuan tentang dampak buruk rokok dengan kadar CO pada pelajar di Kabupaten Indramayu. Pengetahuan merupakan faktor utama yang menentukan perilaku seseorang. Menurut Notoatmodjo (2012) perilaku merupakan respon atau reaksi seseorang terhadap stimulus atau rangsangan dari luar. Perilaku merokok 
JURNAL ILMU KeSEHATAN BHAKTI HUSADA:

HEALTH SCIENCES JOURNAL

VOL. 12 No. 02, DESEMBER 2021

DOI: $10.34305 / \mathrm{JIKBH} . \mathrm{V} 12 \mathrm{I} 2.326$

adalah bentuk respon individu karena adanya stimulus yang berasal dari luar individu. Kurangnya pengetahuan tentang dampak buruk rokok untuk kesehatan bagi seorang remaja akan memicu remaja tersebut untuk berperilaku merokok dan pada akhirnya perilaku merokok tersebut akan berdampak pada kondisi kadar CO pada remaja yang bersangkutan. Studi yang dilakukan oleh Putri (2018) menunjukkan bahwa terdapat korelasi antara jumlah batang rokok dengan kadar CO.

Selanjutnya studi yang dilakukan oleh Rochayati \& Hidayat (2015) menunjukkan adanya pengaruh faktor pengetahuan tentang rokok terhadap perilaku merokok remaja. Remaja yang menjadi perokok berat lebih banyak ditemukan pada kelompok remaja yang memiliki pengetahuan kurang baik dibandingkan dengan remaja dengan pengetahuan baik. Akan tetapi hasil studi yang berbeda menunjukan bahwa tidak adanya hubungan antara pengetahuan tentang dampak buruk rokok dengan kadar CO juga dapat disebabkan karena adanya alasan lain bagi seorang remaja untuk berperilaku merokok. Sebagian besar remaja merokok dengan alasan untuk memperoleh
Ciptaan disebarluaskan di bawah Lisensi Creative Commons AtribusiNonKomersial-BerbagiSerupa 4.0 Internasional.

kenikmatan psikologis, mencari inspirasi dan mencari ketenangan saat kondisi stress atau marah (Anjum et al., 2016; Rosita et al., 2012). Hal ini dapat dilihat bahwa kecenderungan kadar $\mathrm{CO}$ normal pada kelompok yang mengetahui dan tidak mengetahui dampak buruk rokok memiliki proporsi yang hampir sama.

Hasil tabulasi silang antara variabel keberadaan anggota keluarga perokok dengan kadar $\mathrm{CO}$ didapatkan hasil bahwa dari 300 responden yang di lingkungan keluarganya terdapat perokok, sebesar $76,3 \%$ termasuk dalam kategori kadar CO normal dan sebesar $23,7 \%$ dalam kategori kadar CO berbahaya. Sedangkan dari 83 responden yang di lingkungan keluarganya tidak terdapat perokok, sebesar 83,1\% termasuk dalam kategori kadar CO normal dan sebesar $16,9 \%$ termasuk dalam kategori kadar CO berbahaya. Berdasarkan hal tersebut maka dapat dilihat bahwa proporsi kadar CO normal pada kelompok tidak ada anggota keluarga perokok cenderung lebih besar. Sedangkan proporsi kadar CO berbahaya pada kelompok ada anggota keluarga perokok cenderung lebih besar dibandingkan dengan yang tidak ada anggota keluarga perokok. 
JURNAL ILMU KeSEHATAN BHAKTI HUSADA:

HEALTH SCIENCES JOURNAL

VOL. 12 No. 02, DESEMBER 2021

DOI: $10.34305 / \mathrm{JIKBH} . \mathrm{V} 12 \mathrm{I} 2.326$

Hasil analisis chi-square hubungan keberadaan anggota keluarga perokok dengan kadar $\mathrm{CO}$ dapat dilihat dari nilai $\mathrm{p}>0,05$ sehingga menunjukkan tidak terdapat hubungan antara keberadaan anggota keluarga perokok dengan kadar $\mathrm{CO}$ pada pelajar di Kabupaten Indramayu. Diasumsikan bahwa apabila ada anggota keluarga yang merokok di sekitar rumah atau di dalam rumah maka anggota keluarga lain yang berada di lingkungan rumah tersebut akan terpapar asap rokok. Namun hal ini dapat terjadi sebaliknya, apabila ada anggota keluarga yang memiliki kebiasaan merokok namun tidak merokok di dalam rumah ketika ada anggota keluarga yang lain ada maka anggota keluarga tersebut tidak terpapar oleh asap rokok. Sehingga walaupun terdapat anggota keluarga perokok, remaja atau anggota keluarga yang lain memiliki kadar CO pada kategori normal.

Hal ini sejalan dengan pernyataan Inayatillah et al., (2014) yang menyatakan bahwa lingkungan tempat tinggal dengan risiko tinggi paparan $\mathrm{CO}$ dapat mempengaruhi kadar $\mathrm{CO}$ udara ekspirasi namun tidak menunjukkan adanya korelasi yang bermakna.
Ciptaan disebarluaskan di bawah

Lisensi Creative Commons Atribusi-

NonKomersial-BerbagiSerupa 4.0

Internasional.

Hasil tabulasi silang antara variabel keberadaan perokok di sekolah dengan kadar CO diperoleh hasil bahwa dari 329 responden yang ada perokok di lingkungan sekolah sebesar $75,7 \%$ termasuk dalam kategori kadar CO normal dan $24,3 \%$ berada dalam kategori kadar $\mathrm{CO}$ berbahaya. Sedangkan dari 54 responden yang tidak ada perokok di lingkungan sekolah sebesar 90,7\% termasuk dalam kategori kadar $\mathrm{CO}$ normal dan sebesar 9,3\% termasuk dalam kategori kadar CO berbahaya. Berdasarkan hal tersebut maka dapat diketahui bahwa perbedaan proporsi kadar CO berbahaya lebih besar ditemukan pada responden dengan ada perokok di lingkungan sekolah.

Hasil uji chi-square menunjukkan bahawa nilai $p=0,014$. Hal ini menujukkan adanya hubungan antara variabel keberadaan perokok di lingkungan sekolah dengan kadar CO pada pelajar di Kabupaten Indramayu. Lingkungan sekolah merupakan tempat dimana seorang remaja berinteraksi sosial antara dengan masyarakat sekolah seperti dengan teman, guru, petugas keamanan dan orang lain yang berada di sekolah tersebut.

Perilaku teman, guru dan orang lain yang berada di sekolah akan ditangkap 
JURNAL ILMU KESEHATAN BHAKTI HUSADA:

HEALTH SCIENCES JOURNAL

VOL. 12 No. 02, DESEMBER 2021

DOI: $10.34305 / \mathrm{JIKBH} . \mathrm{V} 12 \mathrm{I} 2.326$

sebagai suatu stimulus yang akan dipahami dan menjadi suatu bentuk respon. Pada jam istirahat atau jam kosong ada guru yang merokok di lingkungan sekolah. Perilaku tersebut dilihat oleh para siswa dan dinilai tidak memberi contoh yang baik kepada para peserta didik (Prabasiwi et al., 2017). Terdapat hubungan antara pengaruh guru dengan perilaku merokok siswa $(p=0,000)$. Pengaruh guru secara statistik mempunyai risiko 4,3 kali meningkatkan siswa berperilaku merokok $(\mathrm{OR}=4,375$ CI 95\%: 2,274-8,418) (Destri et al., 2019).

Perilaku yang dilakukan secara berulang-ulang cenderung akan ditiru karena dianggap menjadi suatu hal yang sudah biasa. Pada akhirnya akan berdampak pada kadar CO bagi perokok tersebut atau orang lain yang berada disekitarnya. Dalam penelitian ini menunjukkan bahwa nilai $\mathrm{OR}=3,149 \quad(95 \% \quad \mathrm{CI}=1,213-8,174) \quad$ yang berarti responden dengan keberadaan perokok di lingkungan sekolah mempunyai risiko 3,149 kali lebih besar pada kondisi kadar CO berbahaya dibanding dengan responden yang tidak ada perokok di lingkungan sekolah.

Hasil tabulasi silang antara variabel variabel teman dekat perokok dengan kadar
Ciptaan disebarluaskan di bawah Lisensi Creative Commons AtribusiNonKomersial-BerbagiSerupa 4.0 Internasional.

CO diperoleh hasil bahwa dari 202 responden yang memiliki teman dekat perokok sebesar $71,3 \%$ berada pada kategori kadar CO normal sedangkan sebesar $28,7 \%$ berada pada kategori kadar CO berbahaya. Sedangkan dari 181 responden yang tidak memiliki teman dekat perokok sebesar $85,1 \%$ berada kadar CO normal dan sebesar $14,9 \%$ responden berada pada kategori kadar CO berbahaya. Hal tersebut menunjukkan bahawa perbedaan proporsi kadar $\mathrm{CO}$ berbahaya lebih besar ditemukan pada responden yang memiliki teman dekat perokok. Hasil uji chi-square menunjukkan nilai $\mathrm{P}<0,05$ yang berarti ada hubungan yang signifikan antara keberadaan teman dekat perokok dengan kadar CO pada pelajar di Kabupaten Indramayu.

Hal ini sejalan dengan penelitian yang dilakukan oleh $\mathrm{Br}$ Sinuhaji et al., (2018) menyatakan bahwa teman sebaya memiliki pengaruh terhadap perilaku konsumsi rokok pada remaja. Pada umumnya seorang remaja erat kaitannya dengan berbagai aktivitas yang dilakukan seperti berkumpul bersama teman-teman untuk berolahraga, menjalankan hobi, bermain musik, belajar kelompok berbagi informasi dan pengalaman baik dengan 
JURNAL ILMU KESEHATAN BHAKTI HUSADA:

HEALTH SCIENCES JOURNAL

VOL. 12 No. 02, DESEMBER 2021

DOI: $10.34305 / \mathrm{JIKBH} . \mathrm{V} 12 \mathrm{I} 2.326$

teman sekolah ataupun teman di lingkungan tempat tinggalnya. Adanya perilaku positif ataupun perilaku negatif dalam interaksi sosial diantara para remaja akan berpengaruh terhadap perilaku remaja tersebut. Perilaku negatif remaja seperti kebiasaan merokok akan berdampak pada adanya paparan asap rokok pada individu lainnya sekalipun individu tersebut tidak memiliki kebiasaan merokok. Selain itu perilaku negatif memungkinkan seorang remaja akan mengajak temannya untuk berperilaku yang sama misalnya menawarkan sebatang rokok untuk dikonsumsi.

Semakin sering interaksi sosial diantara para remaja dengan adanya paparan asap rokok maka memungkinkan seseorang berada pada risiko memiliki kadar CO yang lebih tinggi. Selain itu karakteristik remaja yang pada umumnya memiliki rasa ingin tahu dan ingin mencoba hal-hal baru yang dilihat di sekitarnya, maka adanya teman dekat perokok dapat memicu remaja tersebut untuk berperilaku yang sama (Joung et al., 2016).

Hasil penelitian menunjukkan bahwa nilai OR 2,297 (95\% CI=1,379-3,826) yang berarti responden dengan keberadaan teman
Ciptaan disebarluaskan di bawah Lisensi Creative Commons AtribusiNonKomersial-BerbagiSerupa 4.0 Internasional.

dekat perokok memiliki risiko 2,297 kali lebih besar berada pada kondisi kadar CO berbahaya dibandingkan dengan responden yang tidak memiliki teman dekat perokok.

Selanjutnya hasil tabulasi silang antara variabel perilaku merokok dengan kadar CO didapatkan hasil yaitu dari 161 responden yang memiliki perilaku merokok sebesar $60,9 \%$ berada pada kategori kadar CO normal dan $39,1 \%$ berada pada kategori kadar CO berbahaya. Sedangkan dari 222 responden yang tidak merokok sebesar $77,8 \%$ berada pada kategori kadar CO normal dan 9,9\% responden berada pada kategori kadar CO berbahaya. Apabila melihat data tersebut dapat diketahui bahwa proporsi responden dengan kadar $\mathrm{CO}$ berbahaya lebih banyak ditemukan pada responden yang memiliki kebiasaan merokok.

Hal ini sejalan dengan penelitian yang dilakukan oleh Inayatillah et al., (2014) yang mengungkapkan bahwa adanya perbedaan kadar CO pada perokok dan bukan perokok, kadar $\mathrm{CO}$ pada kelompok perokok lebih tinggi dibandingkan bukan perokok. Aktivitas merokok yang dilakukan oleh para remaja mengakibatkan paparan asap rokok baik bagi dirinya sendiri maupun 
JURNAL ILMU KESEHATAN BHAKTI HUSADA:

HEALTH SCIENCES JOURNAL

VOL. 12 No. 02, DESEMBER 2021

DOI: $10.34305 / \mathrm{JIKBH} . \mathrm{V} 12 \mathrm{I} 2.326$

orang lain yang berada disekitarnya. Menurut Tirtosastro dalam Paramitha et al., (2020) salah satu kandungan yang ada dalam asap rokok adalah karbon monoksida (CO) yang memiliki sifat tidak berbau dan beracun. Sementara itu kandungan $\mathrm{CO}$ dalam satu batang rokok sekitar 3\%-6\% dan minimum sejumlah 400 ppm pada saat rokok tersebut dibakar. Hasil penelitian menunjukkan bahwa rata-rata jumlah rokok yang dikonsumsi sebanyak 3 batang/hari.

Hasil uji chi-square menunjukkan bahwa nilai $\mathrm{p}<0,05$ artinya terdapat hubungan antara variabel perilaku merokok dengan kadar CO pada remaja di Kabupaten Indramayu. Nilai OR diperoleh sebesar $5,844(95 \% \mathrm{CI}=3,393-10,051)$ yang berarti responden yang berperilaku merokok memiliki risiko 5,844 kali lebih besar pada kondisi kadar CO berbahaya dibandingkan dengan responden yang tidak merokok. Hasil penelitian ini sejalan dengan studi yang dilakukan oleh Putri (2018) yang menyebutkan bahwa terdapat pengaruh jumlah batang rokok yang dikonsumsi dengan kadar $\mathrm{CO}$, semakin banyak jumlah
Ciptaan disebarluaskan di bawah

Lisensi Creative Commons Atribusi-

NonKomersial-BerbagiSerupa 4.0 Internasional

batang rokok yang dihisap maka kadar $\mathrm{CO}$ akan semakin tinggi (Rufaidah \& Sitorus, 2019).

Selanjutnya untuk mengetahui variabel yang paling dominan berhubungan dengan kadar CO pada pelajar di Kabupaten Indramayu dilakukan analisis multivariat dengan regresi logistik. Analisis multivariat dimulai dengan seleksi variabel yang memiliki nilai $\mathrm{P}<0,25$. Metode yang digunakan yaitu backward LR, dengan metode ini satu persatu variabel akan dikeluarkan mulai dari variabel yang memiliki nilai $\mathrm{p}$ yang paling besar hingga yang memiliki nilai $\mathrm{p}$ terkecil, dimana setiap variabel yang keluar akan didapatkan model yang baru dan seterusnya sehingga didapatkan model akhir.

Adapun variabel yang dimasukan dalam regrsi logistik yaitu keberadaan anggota keluarga perokok, keberadaan perokok di lingkungan sekolah, keberadaan teman dekat perokok dan perilaku merokok. Hasil analisis multivariat dapat dilihat pada tabel 3 berikut ini:

Tabel 3. Model akhir analisis regresi logistik perilaku merokok dan keberadaan perokok di lingkungan dengan kadar CO pada pelajar SMP di Kabupaten Indramayu 
JURNAL ILMU KESEHATAN BHAKTI HUSADA:

HEALTH SCIENCES JOURNAL

VOL. 12 No. 02, DESEMBER 2021

DOI: $10.34305 / \mathrm{JIKBH} . \mathrm{V} 12 \mathrm{I} 2.326$
Ciptaan disebarluaskan di bawah

Lisensi Creative Commons Atribusi-

NonKomersial-BerbagiSerupa 4.0

\begin{tabular}{clcccc}
\hline No & \multicolumn{1}{c}{ Variabel } & B & Sig & Exp (B) & 95\%CI \\
\hline 1. & Perilaku Merokok & 1,747 & 0,000 & 5,738 & $3,326-9,900$ \\
\hline 2. & $\begin{array}{l}\text { Keberadaan Perokok di } \\
\text { Sekolah }\end{array}$ & 1,071 & 0,034 & 2,917 & $1,086-7,838$ \\
\hline$\quad$ Constant & $\mathbf{- 2 . 4 7 8}$ & $\mathbf{0 , 0 0 0}$ & $\mathbf{0 , 0 8 4}$ & \\
\hline
\end{tabular}

Hasil analisis multivariat menunjukkan variabel yang berhubungan dengan kadar $\mathrm{CO}$ adalah perilaku merokok dengan nilai $\quad \mathrm{OR}=5,738 \quad(95 \% \mathrm{CI}=3,326$ 9,900) dan keberadaan dengan perokok di sekolah dengan nilai $\mathrm{OR}=2,917$ (95\% CI $=1,086-7,838)$. Faktor yang paling dominan berhubungan dengan kadar $\mathrm{CO}$ adalah variabel perilaku merokok jika dibandingkan dengan keberadaan perokok di lingkungan sekolah. Kadar CO pada pelajar merupakan resultan dari berbagai faktor yang ada seperti paparan asap rokok baik sebagai perokok aktif maupun sebagai perokok pasif.

Seorang remaja bisa saja tidak merokok namun karena lingkungan dimana ia berinteraksi banyak yang perokok maka secara langsung akan terpapar oleh asap rokok tersebut. Paparan asap pada perokok aktif secara langsung terjadi saat pelajar tersebut membakar rokok kemudian menghisapnya ataupun ketika sedang berinteraksi dengan sesama perokok. Hasil analisis menunjukkan bahwa secara bersama-sama keberadaan perokok di lingkungan sekolah dan perilaku merokok yang dilakukan oleh remaja berhubungan dengan kadar CO pada pelajar di Kabupaten Indramayu.

\section{Kesimpulan dan Saran}

Variabel yang berhubungan dengan kadar CO pada pelajar di Kabupaten Indramayu yaitu keberadaan perokok di lingkungan sekolah, keberadaan teman dekat perokok, dan perilaku merokok. Variabel yang paling dominan berhubungan dengan kadar CO pada remaja yaitu variabel perilaku merokok. Upaya peningkatan kesadaran perlu diberikan kepada para remaja untuk menghindari perilaku merokok.

\section{Daftar Pustaka}

Anjum, M. S., Srikanth, M. K., Reddy, P. P., Monica, M., Rao, K. Y., \& Sheetal, A. (2016). Reasons For Smoking Among The Teenagers Of Age 14-17 Years In Vikarabad Town: A Cross-Sectional Study. Journal of Indian Association of Public Health Dentistry, 14(1), 80. 
JURNAL ILMU KeSEHATAN BHAKTI HUSADA:

HEALTH SCIENCES JOURNAL

VOL. 12 No. 02, DESEMBER 2021

DOI: $10.34305 / \mathrm{JIKBH} . \mathrm{V} 12 \mathrm{I} 2.326$

Badan Kependudukan dan Keluarga Bencana Nasional, Badan Pusat Statistik, \& Kementrian Kesehatan. (2018). Survei Demografi dan Kesehatan Indonesia 2017. Badan Kependudukan dan Keluarga Berencana Nasional.

Br Sinuhaji, E. P., Pangestuti, E., \& Irawan, A. (2018). Pengaruh Lingkungan Keluarga dan Peer Group Terhadap Perilaku Konsumsi Rokok (Survei pada Perokok Kategori Remaja Di Kecamatan Lowokwaru Kota Malang). Jurnal Administrasi Bisnis, 65(1), 102110.

Destri, Y., Sari, F. E., \& Perdana, A. A. (2019). Perilaku Merokok dan Faktor yang Berhubungan pada Siswa. Jurnal Kesehatan Metro Sai Wawai, 12(2), 17-26.

Hosseinpoor, A. R., Parker, L. A., Tursan d'Espaignet, E., \& Chatterji, S. (2011). Social Determinants Of Smoking In Low-And Middle-Income Countries: Results From the World Health Survey. PloS One, 6(5), e20331.

Inayatillah, I. R., Syahrudin, E., \& Susanto, A. D. (2014). Kadar Karbon Monoksida Udara Ekspirasi pada Perokok dan Bukan Perokok Serta Faktor-Faktor yang Mempengaruhi. $J$ Respir Indo, 34(4), 180-190.

Isa, L., Lestari, H., \& Afa, J. R. (2017). Hubungan Tipe Kepribadian, Peran Orang Tua dan Saudara, Peran Teman Sebaya, dan Peran Iklan Rokok dengan Perilaku Merokok pada Siswa SMP Negeri 9 Kendari Tahun 2017. (Jurnal Ilmiah Mahasiswa Kesehatan
Ciptaan disebarluaskan di bawah

Lisensi Creative Commons AtribusiNonKomersial-BerbagiSerupa 4.0 Internasional.

Masyarakat), 2(7).

Iustitiani, N. S. D., \& Ajisuksmo, C. R. P. (2017). Perilaku Berisiko pada Remaja di Kampung Nelayan (Studi Kasus di Desa Eretan Kulon, Indramayu). Prosiding SNaPP2017 Kesehatan, 3(1), 91-98.

Joung, M. J., Han, M. A., Park, J., \& Ryu, S. Y. (2016). Association Between Family and Friend Smoking Status and Adolescent Smoking Behavior and ECigarette Use in Korea. International Journal of Environmental Research and Public Health, 13(12), 1183.

Notoatmodjo, S. (2012). Promosi Kesehatan dan Perilaku Kesehatan. Jakarta: Rineka Cipta, 45-62.

Odukoya, O. O., Odeyemi, K. A., Oyeyemi, A. S., \& Upadhyay, R. P. (2013). Determinants Of Smoking Initiation and Susceptibility to Future Smoking Among School-Going Adolescents in Lagos State, Nigeria. Asian Pacific Journal of Cancer Prevention, 14(3), 1747-1753.

Paramitha, I. A. P. I., Djuni, I. D., \& Setiawan, W. (2020). Rancang Bangun Prototipe Sistem Pendeteksi Asap Rokok Berbasis Mikrokontroler Menggunakan Sensor MQ-2 Dilengkapi dengan Exhaust Fan. Jurnal SPEKTRUM, 7(3).

Prabasiwi, A., Putri, A. R., \& Kusnadi, K. (2017). Perilaku Merokok Guru di Sekolah (Studi Kasus SMP N 13 Kota Tegal). Prosiding 2nd Seminar Nasional IPTEK Terapan (SENIT) 2017, 2(1), 239-242.

Pusat Data dan Informasi Kementrian Kesehatan RI. (2017). Situasi Kesehatan Reproduksi Remaja; Dalam Rangka Hari Keluarga Nasional, 29 Juni. 
JURNAL ILMU KeSEHATAN BHAKTI HUSADA:

HEALTH SCIENCES JOURNAL

VOL. 12 No. 02, DESEMBER 2021

DOI: $10.34305 / \mathrm{JIKBH} . \mathrm{V} 12 \mathrm{I} 2.326$

Pusat Data dan Informasi Kementrian Kesehatan RI. (2018). Situasi Umum Konsumsi Tembakau di Indonesia.

Putri, M. E. (2018). Korelasi Jumlah Batang Rokok Dengan Kadar Co Pada Remaja Perokok Di Smk Kota Jambi. Jurnal Akademika Baiturrahim Jambi, 7(2), 123-129.

Riadinata, E., Abi Muhlisin, H. M., \& SKM, M. K. (2018). Hubungan Lingkungan Keluarga Dan Teman Sebaya Dengan Perilaku Merokok Pada Remaja Di Desa Gonilan Kartasura. Universitas Muhammadiyah Surakarta.

Rochayati, A. S., \& Hidayat, E. (2015). Faktor-Faktor yang Mempengaruhi Perilaku Merokok Remaja di Sekolah Menengah Kejuruan Kabupaten Kuningan. Jurnal Keperawatan Soedirman, 10(1), 1-11.

Rosita, R., Suswardany, D. L., \& Abidin, Z. (2012). Penentu Keberhasilan Berhenti Merokok pada Mahasiswa. KEMAS: Jurnal Kesehatan Masyarakat, 8(1), 19.
Ciptaan disebarluaskan di bawah

Lisensi Creative Commons Atribusi-

NonKomersial-BerbagiSerupa 4.0 Internasional.

Rufaidah, A., \& Sitorus, R. J. (2019). Hubungan Antara Frekuensi Merokok dengan Kadar CO (Karbon Monoksida) pada Perokok di Wilayah Kerja PUSKESMAS Karya Jaya Palembang. Sriwijaya University.

Salim, A. (2018). Skrining Perokok pada Anak SMKN II Kabupaten Indramayu Tahun 2018. Kementrian Kesehatan Republik Indonesia. http://p2ptm.kemkes.go.id/post/skrinin g-perokok-pada-anak-smkn-iikabupaten-indramayu-tahun-2018

Wijayanti, E., \& Dewi, C. (2017). FaktorFaktor Yang Berhubungan Dengan Perilaku Merokok Pada Remaja Kampung Bojong Rawalele, Jatimakmur, Bekasi." Global Medical \& Health Communication (GMHC). 5(3), 194.

Wulandari, A. (2014). Karakteristik Pertumbuhan Perkembangan Remaja dan Implikasinya Terhadap Masalah Kesehatan dan Keperawatannya. Jurnal Keperawatan Anak, 2(1), 3943. 